\title{
PENGEMBANGAN APLIKASI GAME 3D TEBAK RUMAH DAN BUSANA ADAT NUSANTARA BERBASIS ANDROID
}

\author{
Ni Ketut Catur Wahyu Puspitawati ${ }^{1}$, I Made Gede Sunarya ${ }^{2}$, I Ketut Resika Arthana ${ }^{3}$ \\ Jurusan Pendidikan Teknik Informatika \\ Fakultas Teknik dan Kejuruan \\ Universitas Pendidikan Ganesha \\ E-mail : haemosumunsu@gmail.com¹, imadegedesunarya@gmail.com², resika.arthana@gmail.com³
}

\begin{abstract}
Abstrak
Rumah Adat merupakan suatu bangunan yang bisa berwujud rumah tinggal yang diciptakan oleh sekelompok masyarakat generasi dulu yang bersifat tradisional, baik dari segi konsep, makna, hingga desainnya. Busana adat adalah kelengkapan yang dipakai oleh seseorang yang biasanya dipakai untuk memperingati hari besar seperti kelahiran, pernikahan, kematian, serta hari-hari besar keagamaan. Game 3D Tebak Rumah dan Busana Adat Nusantara merupakan sebuah game untuk melestarikan kebudayaan Indonesia, khususnya rumah dan busana adat yang dikemas dalam sebuah teknologi sehingga masyarakat tidak perlu mengeluarkan biaya yang mahal untuk berkunjung ke taman budaya atau berkeliling Indonesia.

Tujuan dari pengembangan aplikasi ini adalah untuk merancang sekaligus mengimplementasikan rancangan dari aplikasi game 3D Tebak Rumah dan Busana Adat Nusantara Berbasis Android. Pengembangan aplikasi ini menggunakan siklus hidup pengembangan perangkat lunak dengan model waterfall. Fitur utama dari game ini adalah permainan tebak rumah dan busana adat (Mulai Permainan), fitur lainnya adalah Pengenalan Objek untuk mengingat bentuk dari rumah dan busana adat Nusantara.

Hasil dari penelitian ini yaitu perancangan dan implementasi Game 3D Tebak Rumah dan Busana Adat Nusantara Berbasis Android telah berhasil dilakukan. Perancangan dilakukan dengan menggunakan model fungsional berupa UML. Diimplementasikan dalam bahasa pemrograman C\# dengan menggunakan game engine Unity3D dan plug-ins ADT serta menggunakan Playmaker sebagai library tambahan. Seluruh kebutuhan fungsional telah berhasil diimplementasikan sesuai dengan rancangan.
\end{abstract}

Kata Kunci : Rumah adat, Busana adat, Game 3D, Android.

\section{Abstract}

Traditional House is a building that can be extant as a residence that created by a group of people who are the traditional first generation, both in terms of concept, meaning, to the design. Traditional cloth is worn by a person completeness normally used to mark the big day such as birth, marriage, death, and religious days. 3D Game Guess Traditional House and Cloth is a game to preserve Indonesian culture, especially it is packaged in a technology so that people do not need to spend expensive cost for a visit to the park or around the culture of Indonesia.

The purpose of developing this application is to design and implement the design of applications 3D Game Guess Traditional House and Cloth -Based Indigenous Android. The development of application uses software development life cycle waterfall model. The main feature of this game is a guessing traditional house game and the traditional cloth (Start Game), another feature is the introduction of object to remember the shape of the traditional house and traditional cloth archipelago.

The result of this research is the design and implementation of 3D Game Guess Traditional House and Cloth -Based Indigenous Android has been successfully carried out. The design is done by using the functional form of UML models. It is implemented in $\mathrm{C}$ \# programming language by using the Unity3D game engine and the ADT plug-ins and use playmaker as additional libraries. The entire functional requirements have been successfully implemented in accordance with the design.

Keyword : Traditional House, Traditional Cloth, 3D Game, Android.

PENDAHULUAN

Pengembangan Aplikasi Game 3D ..... (Ni Ketut Catur Wahyu Puspitawati, I Made Gede Sunarya, I

Ketut Resika Arthana) 
atas provinsi. Masing - masing provinsi memiliki keanekaragaman seni dan budaya, Kebudayaan sangat lekat dengan kehidupan sehari - hari masyarakat. Faktor iklim, lingkungan, dan cuaca yang berbeda, kebudayaan yang dimiliki oleh kelompok masyarakat tertentu akan berbeda dengan kelompok masyarakat lainnya dan terlihat dari berbagai hasil karya masyarakat seperti rumah adat, pakaian adat, senjata tradisional, tarian, dan lain sebagainya.

Rumah Adat merupakan suatu bangunan yang bisa berwujud rumah tinggal yang diciptakan oleh sekelompok masyarakat generasi dulu yang bersifat tradisional, baik dari segi konsep, makna, hingga desainnya. Busana adat adalah kelengkapan yang dipakai oleh seseorang yang biasanya dipakai untuk memperingati hari besar seperti kelahiran, pernikahan, kematian, serta hari-hari besar keagamaan.

Warisan budaya yang sangat kaya ini patut dilestarikan oleh masyarakat Indonesia. Adapun beberapa upaya pemerintah untuk tetap melestarikan simbol - simbol kebudayaan seperti rumah dan busana adat adalah dengan membangun taman rekreasi kebudayaan yaitu Taman Mini Indonesia Indah yang terletak di Jakarta Timur. Taman Mini Indonesia Indah (TMII) dan Taman Nusa yang terletak di Banjar Blahpane Kelod, Desa Sidan, Kabupaten Gianyar. Akan tetapi masih memiliki keterbatasan yakni lokasi yang jauh, biaya tiket yang cukup mahal, serta harus meluangkan waktu yang cukup untuk berekreasi ke tempat tersebut.

Pemerintah juga mengupayakan pelestarian kebudayaan daerah Indonesia melalui bidang pendidikan dengan mengajarkan ragam suku bangsa dan budaya, serta pelestarian budaya Indonesia yang tertuang dalam mata pelajaran IImu Pengetahuan Sosial (IPS) di tingkat Sekolah Dasar. Akan tetapi, materi mengenai pengenalan rumah dan busana adat dirasa kurang menarik, karena ditampilkan dalam buku paket SD yang sebagian besar hanya berwarna hitam putih, rumah dan busana adat yang ditampilkan kurang lengkap, yakni hanya menyertakan beberapa rumah dan busana adat yang terkenal.
Oleh karena kurangnya minat kalangan muda dan anak - anak untuk mengenal kebudayaan ini, maka diperlukan suatu strategi untuk menarik minat mereka, seperti membuatkan sebuah Game. Game tidak hanya bermanfaat agar memperoleh kesenangan, kepuasan, ataupun merubah suasana hati, tetapi game juga bermanfaat sebagai media edukatif. Peneliti ingin agar orang - orang dapat memainkan game yang bermanfaat dan mendidik, oleh karena itu dalam penelitian ini peneliti akan memanfaatkan teknologi untuk mengembangkan sebuah game mengenai kebudayaan yang dapat digunakan sebagai media untuk memperoleh kesenangan sekaligus pembelajaran.

Contoh dari game kebudayaan adalah Fahombo, Mancala, Nguri Budaya, Inheritage, dan Hasami Shogi. Fahombo adalah game yang mengangkat tentang kebudayaan loncat batu di pulau Nias [5], game ini sangat bagus untuk memperkenalkan kebudayaan Indonesia, akan tetapi game ini tidak memiliki mode latihan, sehingga menyulitkan pemain pemula yang tidak mengetahui kebudayaan ini. Berdasarkan tinjauan tersebut, peneliti ingin mengembangkan sebuah game kebudayaan Nusantara.

Salah satu sistem operasi yang saat ini banyak digunakan adalah Android, karena sistem operasi ini digunakan pada perangkat mobile. Oleh sebab itulah peneliti tertarik mengembangkan aplikasi berbasis Android tentang kebudayaan yang berjudul "Pengembangan Aplikasi Game 3D Tebak Rumah dan Busana Adat Nusantara Berbasis Android".

\section{KAJIAN TEORI}

A. Rumah dan Busana Adat

Rumah Adat merupakan suatu bangunan yang bisa berwujud rumah tinggal atau fungsi bangunan lain yang diciptakan oleh sekelompok masyarakat generasi sebelum sekarang yang bersifat tradisional, baik dari segi konsep, makna, hingga desainnya. Di Indonesia, setiap suku memiliki bangunan adat dengan karakter dan bentuknya serta cirinya masing-masing sebagai bagian dari budayanya. Sebagai negara yang kaya 
dengan budaya, tentunya Indonesia mempunyai koleksi bangunan adat yang tersebar dari Sabang sampai Merauke. Berikut adalah rumah - rumah adat yang tersebar diseluruh Indonesia . Contoh rumah adat sebagai berikut.

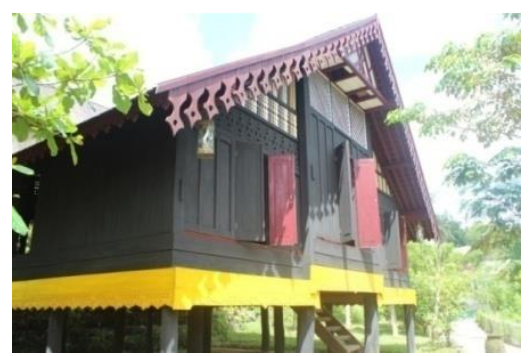

Gambar 1. Rumah adat Aceh

Pakaian adat merupakan simbol
kebudayaan suatu daerah. Untuk menunjukkan nama daerah pakaian adat pun bisa dijadikan simbol tersebut. Pasalnya, setiap daerah di Indonesia memiliki pakaian adat yang berbeda-beda. Pakaian adat biasanya dipakai untuk memperingati hari besar seperti kelahiran, pernikahan, kematian, serta hari-hari besar keagamaan. Setiap daerah memiliki pengertian pakaian adat sendiri-sendiri. Sebagai simbol, pakain adat memang dijadikan penanda untuk sesuatu. Biasanya berupa doa atau mencerminkan suatu sikap.

Pakaian adat Indonesia adalah kelengkapan yang dipakai oleh seseorang, khususnya Indonesia yang menunjukkan etos kebudayaan masyarakat Indonesia. Pakaian adat Indonesia tersebut bermacam-macam sesuai dengan daerah yang ada di Indonesia. Contoh busana adat sebagai berikut.

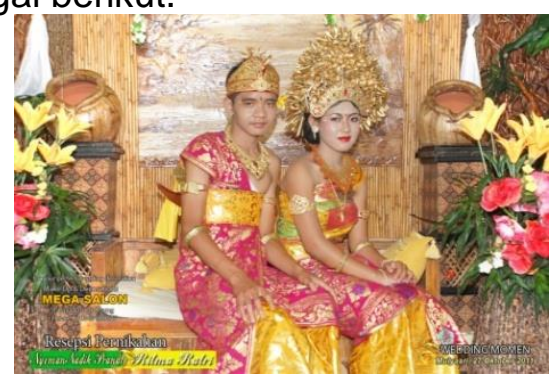

Gambar 2. Busana adat Bali

\section{B. Game}

Dalam kamus bahasa Indonesia "Game" adalah permainan. Permainan adalah kegiatan yang kompleks yang didalamnya terdapat peraturan, play dan budaya. Sebuah permainan adalah sebuah sistem dimana pemain terlibat dalam konflik buatan, disini pemain berinteraksi dengan sistem dan konflik dalam permainan merupakan rekayasa atau buatan, dalam permainan terdapat peraturan yang bertujuan untuk membatasi perilaku pemain dan menentukan permainan. Game bertujuan untuk menghibur, biasanya game banyak disukai oleh anak - anak hingga orang dewasa. Games sebenarnya penting untuk perkembangan otak, untuk meningkatkan konsentrasi dan melatih untuk memecahkan masalah dengan tepat dan cepat karena dalam game terdapat berbagai konflik atau masalah yang menuntut kita untuk menyelesaikannya dengan cepat dan tepat.

\section{Android}

Android merupakan sebuah sistem operasi untuk perangkat mobile berbasis Linux yang mencangkup sistem operasi, middleware dan aplikasi. Android menyediakan platform terbuka bagi para pengembang untuk menciptakan aplikasi mereka. Android Inc. adalah sebuah perusahaan perangkat hardware ponsel yang terletak di Palo Alto, California Amerika Serikat. Sejak Juli 2000, Android bekerjasama dengan perusahaan Google Inc untuk mengembangkan sistem operasi untuk ponsel. Berikut merupakan versi dari sistem operasi Android dari awal perkembangannya hingga sekarang. Android versi 1.1, Android versi 1.5 (Cupcake), Android versi 1.6 (Donut), Android versi 2.0/2.1 (Eclair), Android versi 2.2 (Froyo : Frozen Yoghurt), Android versi 2.3 (Gingerbread), Android versi 3.0/3.1 (Honeycomb), Android versi 4.0 (Ice Cream Sandwich), Android versi 4.1 (Jelly Bean), dan Android versi 4.4 (Kitkat).

\section{Unity 3D}

Unity $3 D$ merupakan sebuah tools yang terintegrasi untuk membuat bentuk obyek tiga dimensi pada video games atau untuk konteks interaktif lain seperti visualisasi arsitektur atau animasi $3 D$ realtime. Lingkungan dari pengembangan Unity

Pengembangan Aplikasi Game 3D ..... (Ni Ketut Catur Wahyu Puspitawati, I Made Gede Sunarya, I

Ketut Resika Arthana) 
$3 D$ berjalan pada Microsoft Windows dan Mac Os X, serta aplikasi yang dibuat oleh Unity $3 D$ dapat berjalan pada Windows, Mac, Xbox 360, Playstation 3, Wii, iPad, iPhone dan tidak ketinggalan pada platform Android. Unity juga dapat membuat game berbasis browser yang menggunakan Unity web player plugin, yang dapat bekerja pada Mac dan Windows, tapi tidak pada Linux. Web player yang dihasilkan juga digunakan untuk pengembangan pada widgets Mac.

Adapun fitur-fitur yang dimiliki oleh

Unity $3 D$ antara lain sebagai berikut.

1. Integrated development environment (IDE) atau lingkungan pengembangan terpadu.

2. Penyebaran hasil aplikasi pada banyak platform.

3. Engine grafis menggunakan Direct3D (Windows), OpenGL (Mac, Windows), OpenGL ES (iOS), dan proprietary API (Wii).

Game Scripting melalui Mono Scripting yang dibangun pada Mono, implementasi open source dari NET Framework. Selain itu pemrograman dapat menggunakan Unity Script (bahasa kustom dengan sintaks Java Script-inspired), bahasa C\# atau Boo (yang memiliki sintaks Python-inspired).

\section{E. Blender}

Blender merupakan perangkat lunak untuk membuat animasi tiga dimensi yang berbasis bebas bayar. Selain itu, perangkat lunak ini juga dapat digunakan untuk membuat game tiga dimensi.

Seperti pada perangkat lunak tiga dmensi lainnya, pada Blender pembentukan objek dibuat dari objek-objek primitif. Yang termasuk objek-objek primitif adalah kubus, plane, kerucut, lingkaran dan tabung. Dengan manipulasi objek primitif tersebut kita dapat membuat objek tiga dimensi yang kita inginkan. Untuk mempermudah dalam memanipulasi objek kita dapat melihat tampilan dari berbagai sudut. Dengan demikian, dapat terlihat jelas semua bagian dari objek yang akan dibuat.

\section{METODOLOGI}

Pengembangan Aplikasi Game 3D Tebak Rumah dan Busana Adat Nusantara berbasis Android ini mengunakan proses SDLC (System Development Life Cycle) dengan model waterfall yaitu model yang bersifat sistematis dan berurutan dalam membangun perangkat lunak, mulai dari tahap analisis, desain, implementasi, evaluasi.

Tahap pertama yang dilakukan adalah penulis melakukan pencarian informasi dan menganalisis kenyataan tentang pengetahuan masyarakat umum mengenai rumah dan busana adat yang ada di indonesia. Berdasarkan hasil analisis penulis bahwa hanya sebagian kecil masyarakat yang mengetahui keanekaragaman budaya terutama rumah dan busana adat nusantara. Masyarakat dapat mempelajari tentang ini dengan berkunjung ke tempat rekreasi seperti Taman Mini Indonesia Indah yang terletak di Jakarta Timur. Taman Mini Indonesia Indah yang berada di Jakarta Timur dan Taman Nusa yang berada di Gianyar, Bali. Akan tetapi kedua tempat rekreasi ini memiliki keterbatasan yakni lokasi yang jauh, biaya tiket yang cukup mahal, serta harus meluangkan waktu yang cukup untuk berekreasi ke tempat tersebut.

Selain itu, masyarakat juga dapat mempelajarinya melalui buku Atlas, buku Geografi, buku IPS kelas IV yang memuat ragam suku bangsa dan budaya beserta pelestarian budaya Indonesia, serta buku umum lainya. Akan tetapi, materi mengenai pengenalan rumah dan busana adat dirasa kurang menarik, karena ditampilkan dalam buku paket SD yang sebagian besar hanya berwarna hitam putih, rumah dan busana adat yang ditampilkan kurang lengkap, yakni hanya menyertakan beberapa rumah dan busana adat yang terkenal.

Solusi yang peneliti usulkan berdasarkan permasalahan di atas adalah dengan mengembangkan sebuah aplikasi permainan tebak rumah dan busana adat yang dikembangkan pada sistem operasi Android. Dengan nama Game 3D Tebak Rumah dan Busana Adat Nusantara berbasis Android. Dengan dikembangkannya aplikasi ini, diharapkan akan dapat menambah pengetahuan masyarakat umum serta siswa mengenai keanekaragaman rumah dan busana adat di Indonesia tanpa harus mengeluarkan biaya yang mahal untuk berkeliling 
Indonesia atau bepergian jauh ke tempat rekreasi budaya.

A. Analisis Perangkat Lunak

1. Kebutuhan Perangkat Lunak

Berdasarkan analisis terhadap

Aplikasi Game 3D Tebak Rumah dan Busana Adat Nusantara Berbasis Android, terdapat proses-proses yang akan diimplementasikan, yaitu:

1. Aplikasi ini dapat menampilkan menu utama yang terdiri dari Mulai Permainan, Cara Bermain, Pengenalan Objek, Tentang.

2. Aplikasi ini dapat menampilkan karakter $3 D$ rumah dan busana adat beserta daerah / provinsi asalnya sehingga user dapat mengingat daerah asal dari karakter $3 D$ rumah dan busana saat memainkan Game.

3. Aplikasi ini dapat menampilkan permainan yang dapat menguji pengetahuan tentang nama rumah dan busana adat di Nusantara.

4. Aplikasi ini dapat menampilkan menu Cara Bermain untuk membantu pengguna dalam menggunakan aplikasi ini.

5. Aplikasi ini dapat memutar objek $3 D$ rumah dan busana pada menu Pengenalan Objek

2. Tujuan Pengembangan Perangkat Aplikasi Game 3D Tebak Rumah dan Busana Adat Nusantara Berbasis Android merupakan perangkat lunak yang digunakan untuk memperkenalkan sekaligus melestarikan rumah dan busana adat nusantara melalui sebuah game dengan objek $3 D$ dari rumah dan busana adat tersebut. Aplikasi ini diharapkan mampu memenuhi proses-proses sebagai berikut:

a. Mampu menampilkan menu utama yang terdiri dari Mulai Permainan, Cara Bermain, Pengenalan Objek, Tentang.

b. Mampu menampilkan karakter $3 D$ rumah dan busana adat beserta daerah / provinsi asalnya sehingga user dapat mengingat daerah asal dari karakter $3 D$ rumah dan busana saat memainkan Game.

c. Mampu menampilkan permainan yang dapat menguji pengetahuan tentang nama rumah dan busana adat di Nusantara.

d. Mampu menampilkan menu Cara Bermain untuk membantu pengguna dalam menggunakan aplikasi ini.

Mampu memutar objek 3D rumah dan busana pada menu Pengenalan Objek

3. Masukan dan Keluaran Perangkat Lunak

Masukan dalam perangkat lunak Game 3D Tebak Rumah dan Busana Adat Nusantara Berbasis Android adalah berupa sentuhan (touch) pada layar saat bermain game atau mengenal objek rumah dan busana adat. suara dari permainan dan skor yang diperoleh setelah permainan selesai. Keluaran dari perangkat lunak ini adalah suara dari permainan dan objek $3 D$ yang bisa diputar saat pengenalan objek dan pada permainan.

\section{B. Perancangan atau Desain Perangkat Lunak}

1. Model Fungsional Perangkat Lunak

Dalam pengembangan aplikasi ini, peneliti menggunakan dua macam diagram yaitu use-case diagram, dan activity diagram.

\section{a. Use Case Diagram}

Use case diagram menggambarkan fungsionalitas yang diharapkan dari sebuah sistem. Sebuah use case merepresentasikan sebuah interaksi antara aktor dengan sistem. Seorang/sebuah aktor adalah sebuah entitas manusia atau mesin yang berinteraksi dengan sistem untuk melakukan pekerjaan-pekerjaan tertentu. Use case diagram tersebut dapat dilihat pada Gambar 3. 


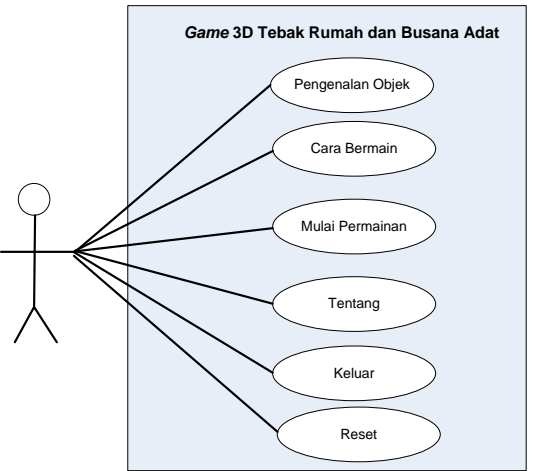

Gambar 3. Use Case Diagram Perangkat Lunak Game 3D Tebak Rumah dan Busana Adat Nusantara Berbasis Android (Sumber: hasil pengamatan peneliti)

\section{b. Activity Diagram}

Activity diagram menggambarkan berbagai alir aktivitas dalam sistem yang sedang dirancang, bagaimana masingmasing alir berawal, decision yang mungkin terjadi, dan bagaimana mereka berakhir. Berdasarkan use case diagram yang sudah dijelaskan di atas, maka dapat ditentukan activity diagram dari aplikasi Game 3D Tebak Rumah dan Busana Adat Nusantara Berbasis Android seperti terlihat pada Gambar 4.

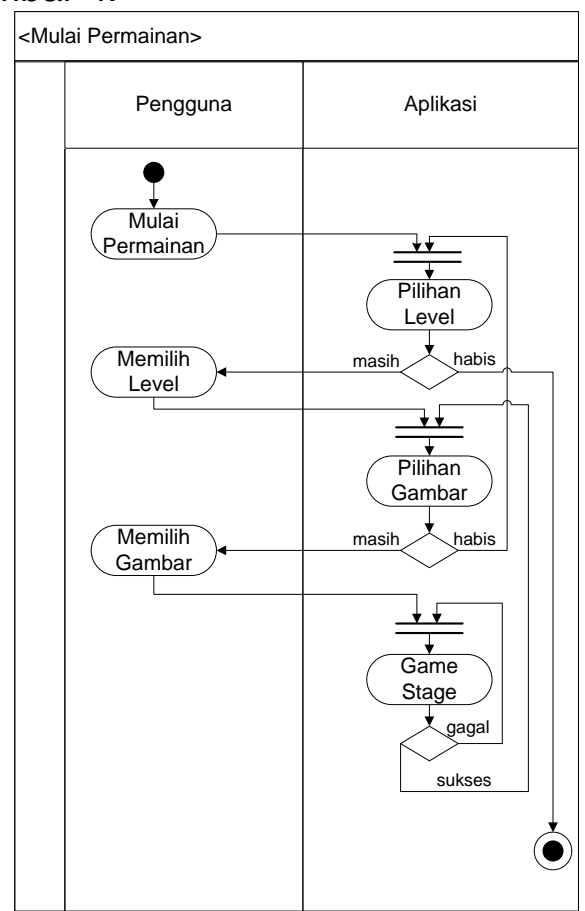

Gambar 4. Activity Diagram Menu Mulai Permainan (Sumber : Hasil Pengamatan Sendiri)
2. Batasan Perancangan Perangkat Lunak Adapun batasan perancangan perangkat lunak Aplikasi Game 3D Tebak Rumah dan Busana Adat Nusantara berbasis Android dapat dipaparkan sebagai berikut.

1. Aplikasi yang dikembangkan akan menampilkan rumah dan busana adat diseluruh provinsi di Indonesia yang saat ini berjumlah 34 provinsi.

2. Rumah dan Busana Adat akan dibuat dalam bentuk objek $3 D$

3. Aplikasi ini hanya dapat berjalan pada perangkat android versi 4.0 (IceCreamSandwich) ke atas, dengan OpenGL ES diatas 2.0, dan arsitektur ARMv7.

\section{Perancangan Struktur Navigasi Perangkat Lunak}

Struktur navigasi merupakan struktur atau alur dari suatu program. Struktur navigasi juga memberikan kemudahan dalam menganalisa keinteraktifan seluruh objek dalam aplikasi dan bagaimana pengaruh keinteraktifannya terhadap pengguna.

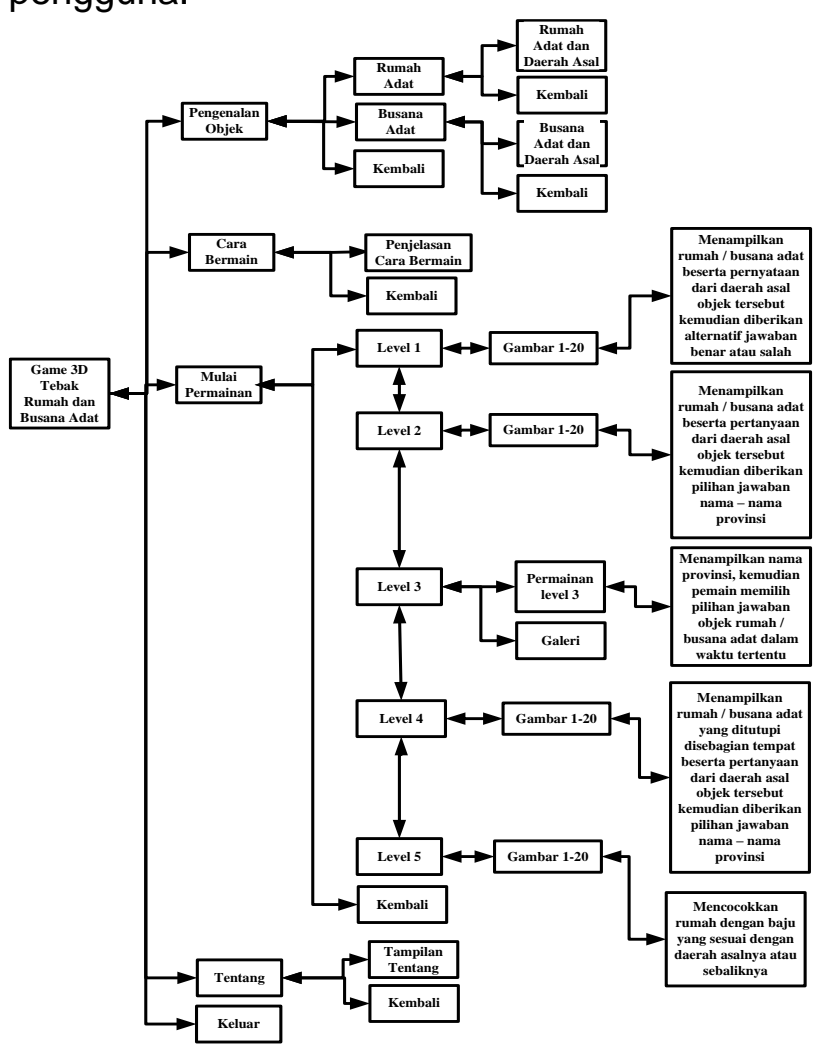


Gambar 5. Struktur Navigasi Game 3D Tebak Rumah dan Busana Adat Berbasis Android

\section{Perancangan Struktur Data Perangkat} Lunak

Perancangan struktur data perangkat lunak merupakan tahap pendefinisian dari kebutuhan-kebutuhan fungsional dalam suatu tahap pengembangan sistem. Perancangan struktur data aplikasi Aplikasi Game 3D Tebak Rumah dan Busana Adat Nusantara berbasis Android terlihat pada Tabel 2 berikut.

Tabel 2. Struktur Data Perangkat Lunak

\begin{tabular}{|r|l|l|}
\hline No & \multicolumn{1}{|c|}{ Tipe } & \multicolumn{1}{|c|}{ Keterangan } \\
\hline 1. & $\begin{array}{l}\text { Library } \\
\left({ }^{*} . \text { unitypac }\right. \\
\text { kage })\end{array}$ & $\begin{array}{l}\text { Format/tipe data } \\
\text { pendukung } \\
\text { pengembangan } \\
\text { aplikasi berupa } \\
\text { library playmaker }\end{array}$ \\
\hline 2. & $\left({ }^{*}\right.$.unity) & $\begin{array}{l}\text { Pendefinisian scene } \\
\text { project pada } \\
\text { Unity3D sebagai } \\
\text { antarmuka sistem. }\end{array}$ \\
\hline 3. & $\begin{array}{l}\text { Audio } \\
\text { Source }\end{array}$ & $\begin{array}{l}\text { Komponen pada } \\
\text { Unity 3D untuk } \\
\text { pengaturan } \\
\text { suara/audio aplikasi. }\end{array}$ \\
\hline 4. & $\begin{array}{l}\text { Game } \\
\text { Object }\end{array}$ & $\begin{array}{l}\text { Digunakan untuk } \\
\text { menyimpan script } \\
\text {-cs yang berupa soft } \\
\text { button pada Unity } \\
\text { 3D. }\end{array}$ \\
\hline 5. & GUI \\
& Tekstur & $\begin{array}{l}\text { Digunakan untuk } \\
\text { membuat softkey } \\
\text { Touch to Reset dan } \\
\text { Touch to Rotate }\end{array}$ \\
\hline
\end{tabular}

6. Perancangan Antarmuka Perangkat Lunak

Perancangan antarmuka perangkat lunak Game 3D Tebak Rumah dan Busana Adat Nusantara berbasis Android adalah sebagai berikut.

a. Perancangan Antarmuka Menu Utama

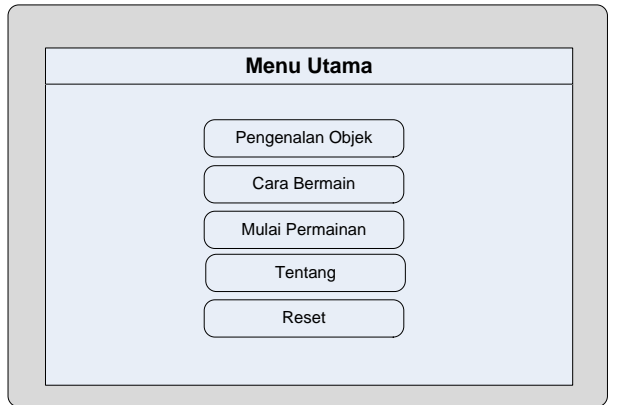

Gambar 6. Rancangan Antarmuka Menu Utama

b. Perancangan Antarmuka Menu Mulai Permainan

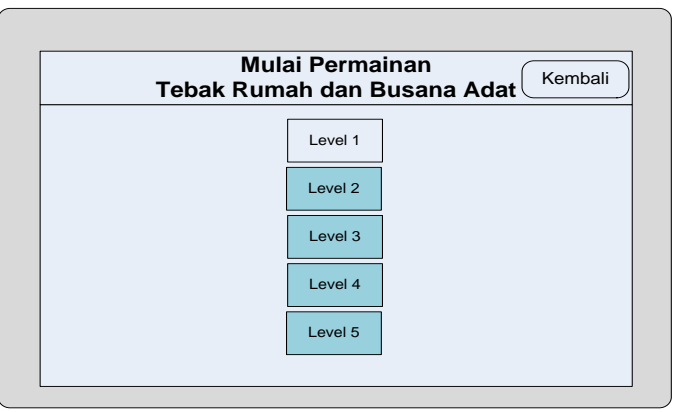

Gambar 7. Rancangan Antarmuka Menu Mulai Permainan

c. Perancangan Antarmuka Sub Menu Level 1

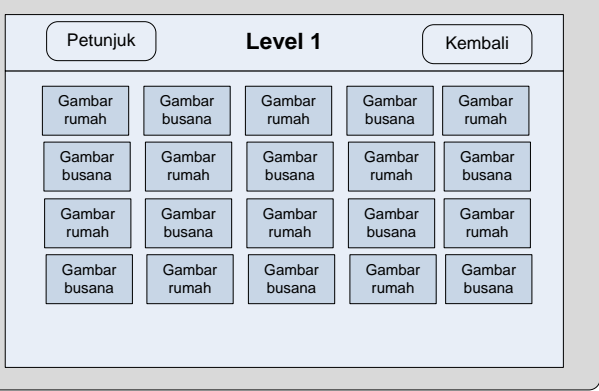

Gambar 8. Rancangan Antarmuka Sub Menu Level 1

d. Perancangan Antarmuka Gambar Terpilih Level 1

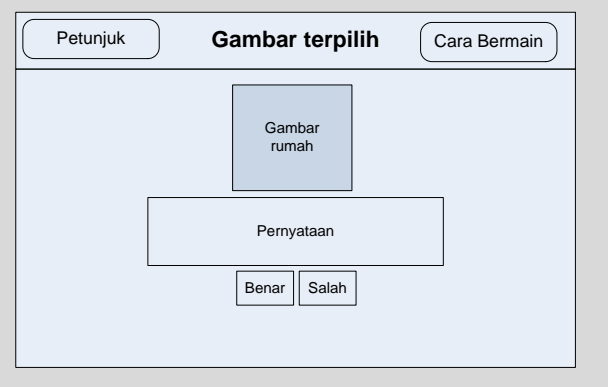

Pengembangan Aplikasi Game 3D ..... (Ni Ketut Catur Wahyu Puspitawati, I Made Gede Sunarya, I Ketut Resika Arthana) 
Gambar 9. Rancangan Antarmuka Gambar Terpilih Level 1

e. Perancangan Antarmuka Petunjuk

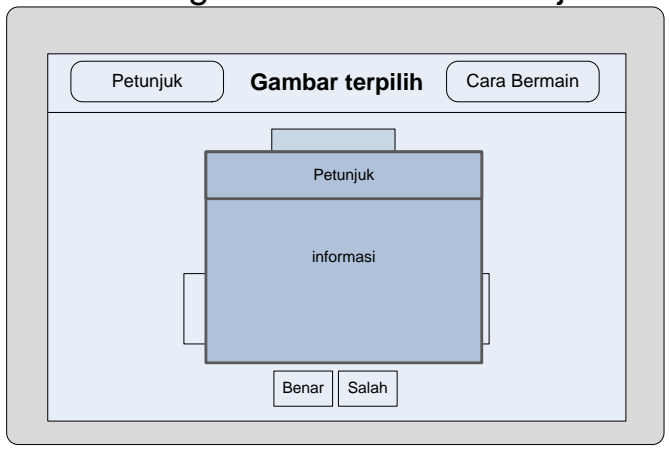

Gambar 10. Rancangan Antarmuka Petunjuk

C. Implementasi Perangkat Lunak

Aplikasi Game 3D Tebak Rumah dan

Busana Adat Nusantara berbasis Android diimplementasikan dalam lingkungan Sistem Operasi Windows 7 Ultimate dan Sistem Operasi Android Jelly Bean dengan menggunakan perangkat lunak Unity3D sebagai Engine dengan bahasa pemrograman C\#.

Perangkat keras yang digunakan adalah seperangkat komputer dengan spesifikasi Intel Core $^{\mathrm{TM}}$ i5-720QM CPU @ 1.60GHz, VGA NVIDIA GeForce GTX 550 Ti 1GB GDDR5, serta dilengkapi alat input dan output.

\section{Pengujian dan Evaluasi Perangkat} Lunak

Pengujian perangkat lunak merupakan proses menjalankan dan mengevaluasi sebuah perangkat lunak untuk menguji apakah perangkat lunak sudah memenuhi persyaratan atau belum untuk menentukan perbedaan antara hasil yang diharapkan dengan hasil sebenarnya.

Pengujian perangkat lunak ini mempergunakan pengujian blackbox testing. Dimana pengujian ini hanya dilihat berdasarkan keluaran yang dihasilkan dari data atau kondisi masukan yang diberikan untuk fungsi yang terdapat pada perangkat lunak. Pengujian ini dilakukan dengan angket Kebenaran Proses Perangkat Lunak, Perbandingan Gambar 2D dengan
Objek 3D, dan Perbandingan dari Hardware yang Berbeda.

Setelah melaksanakan pengujian, maka hasil pengujian akan dievaluasi untuk memperoleh kesimpulan dari aplikasi yang telah dibuat.

\section{IMPLEMENTASI DAN EVALUASI}

A. Implementasi Perangkat Lunak

1. Lingkungan Implementasi Perangkat Lunak

Lingkungan implementasi perangkat lunak Game 3D Tebak Rumah dan Busana Adat Nusantara Berbasis Android menggunakan beberapa perangkat lunak dan perangkat keras sebagai berikut. Pada lingkungan perangkat lunak yaitu Sistem Operasi Microsoft Windows 7 Ultimate, Sistem Operasi Android JellyBean v4.2.2, Blender 2.70a., CLO3D 2011 v4.0.3, Unity4.2.0f4., SDK Android Tools, Adobe Photoshop CS6.

Pada lingkungan perangkat keras yaitu komputer dengan spesifikasi Intel@Core ${ }^{\mathrm{TM}}$ i5-720QM CPU @ 1.60GHz, VGA NVIDIA GeForce GTX 550 Ti 1GB GDDR5, RAM 8.00 GB, Harddisk 500 GB, serta dilengkapi alat input dan output.

Perangkat keras lainnya yaitu Tablet Samsung Galaxy Note 8.0., resolusi $800 x$ 1280 pixels, 8,0 inches., processor Quadcore 1,6 GHz Cortex - A9., RAM 2 GB.

2. Batasan Implementasi Perangkat Lunak Batasan yang terdapat dalam implementasi perangkat lunak Game 3D Tebak Rumah dan Busana Adat Nusantara Berbasis Android yaitu sebagai berikut.

a. Spesifikasi perangkat minimal yang diperlukan untuk menjalankan aplikasi adalah sebagai berikut.

a) Processor ARM-v7a

b) GPU kelas mid-end

c) OS Android versi 4.0 (IceCreamSandwich)

b. Tidak dapat menambah atau mengubah objek $3 D$ rumah dan busana adat.

c. Hanya dapat merotasikan objek ke arah kiri dan kanan.

3. Implementasi Antarmuka Perangkat Lunak 
Implementasi antarmuka dilakukan sesuai dengan rancangan antarmuka yang telah dibuat sebelumnya.

a. Implementasi Antarmuka Menu Utama

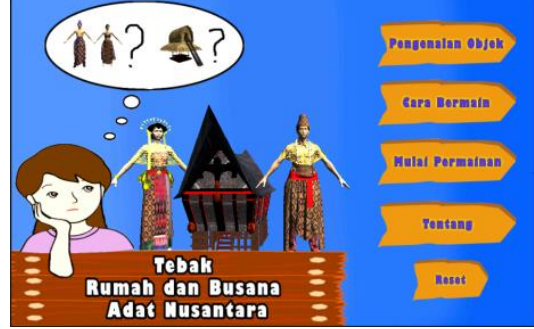

Gambar 11. Implementasi Antarmuka Menu Utama

b. Implementasi Antarmuka Mulai Permainan

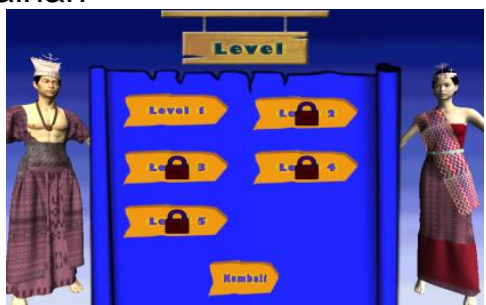

Gambar 12. Implementasi Antarmuka Mulai Permainan

c. Implementasi Antarmuka Sub Menu Level 1

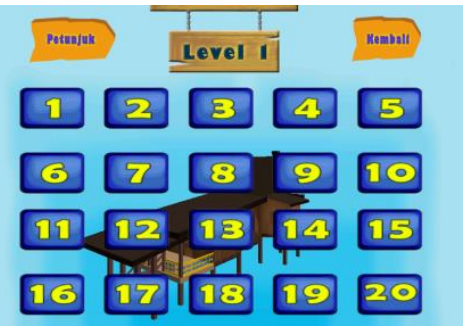

Gambar 13. Implementasi Antarmuka Sub Menu Level 1

d. Implementasi Antarmuka Gambar Terpilih Level 1

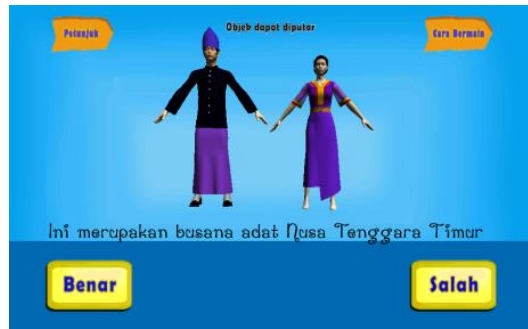

Gambar 14. Implementasi Antarmuka Gambar Terpilih Level 1

e. Implementasi Antarmuka Petunjuk

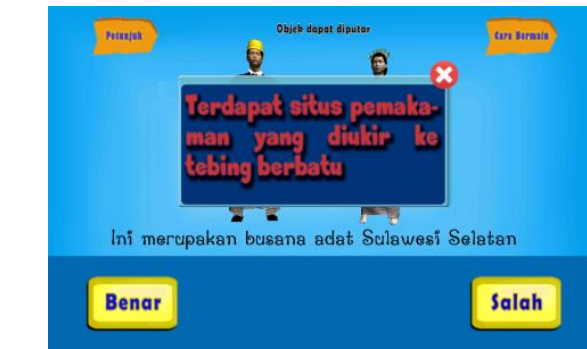

Gambar 15. Implementasi Antarmuka Petunjuk

B. Evaluasi Perangkat Lunak

1. Tujuan Pengujian Perangkat Lunak Adapun tujuan pengujian aplikasi Game 3D Tebak Rumah dan Busana Adat Nusantara Berbasis Android adalah:

1. Menguji penggunaan aplikasi Game 3D Tebak Rumah dan Busana Adat Nusantara Berbasis Android pada perangkat Android yang berbeda.

2. Menguji kesesuain antara gambar rumah dan busana adat dengan objek $3 D$.

3. Menguji kebenaran proses aplikasi Game 3D Tebak Rumah dan Busana Adat Nusantara Berbasis Android.

2. Perancangan Kasus Uji Pengujian Perangkat Lunak

Pada tahap ini dideskripsikan secara mendetail bentuk bentuk uji kasus yang akan dilaksanakan sesuai dengan tujuan pengujian dan tata ancang pengujian yang telah ditetapkan. Uji kasus yang dibuat selengkap mungkin agar hasil pengujian lebih valid. Terdapat empat kasus uji yang dirancang sesuai dengan tujuan pengujian perangkat lunak yang digambarkan dengan angket pengujian.

\section{Pelaksanaan Pengujian Perangkat Lunak}

Berdasarkan perancangan pengujian perangkat lunak di atas, maka pengujian aplikasi Game 3D Tebak Rumah dan Busana Adat Nusantara Berbasis Android dilakukan oleh: 1) Pengembang untuk pengujian kesesuai proses aplikasi. 2) Empat orang yang diambil secara acak, yaitu mahasiswa dari Universitas Pendidikan Ganesha, Singaraja. Pengujian dilakukan sesuai dengan kasus uji yang telah dirancang sebelumnya dan menggunakan angket yang dilaksanakan pada hari Kamis, 30 Oktober 2014. Untuk

Pengembangan Aplikasi Game 3D ..... (Ni Ketut Catur Wahyu Puspitawati, I Made Gede Sunarya, I Ketut Resika Arthana) 
lebih jelasnya berikut akan dijabarkan secara mendetail pelaksanaan pengujian perangkat lunak.

\section{Evaluasi Hasil Pengujian Perangkat Lunak \\ Berdasarkan pengujian pada Uji Kasus} 1 diketahui bahwa aplikasi Game 3D Tebak Rumah dan Busana Adat Nusantara Berbasis Android dapat dijalankan pada semua perangkat Android sesuai dengan kebutuhan minimum aplikasi yang telah ditetapkan. Berdasarkan pengujian pada Uji Kasus 2 diketahui bahwa semua objek $3 D$ yang terdapat pada aplikasi Game $3 D$ Tebak Rumah dan Busana Adat Nusantara Berbasis Android mirip atau sesuai dengan gambar 2D-nya. Berdasarkan pengujian pada Uji Kasus 3 diketahui bahwa semua fitur yang terdapat pada aplikasi Game 3D Tebak Rumah dan Busana Adat Nusantara Berbasis Android dapat berjalan dengan baik sesuai dengan fungsinya masingmasing.

\section{SIMPULAN}

Berdasarkan hasil analisis, implementasi dan pengujian pada penelitian pengembangan aplikasi Game 3D Tebak Rumah dan Busana Adat Nusantara Berbasis Android, dapat ditarik kesimpulan sebagai berikut.

1. Aplikasi Game $3 D$ Tebak Rumah dan Busana Adat Nusantara Berbasis Android merupakan sebuah permainan untuk mengingat serta memahami keanekaragaman bentuk, corak, warna dari rumah dan busana adat Nusantara.

2. Aplikasi Game 3D Tebak Rumah dan Busana Adat Nusantara Berbasis Android dirancang berdasarkan skenario game, serta menggunakan Use Case Diagram dan Activity Diagram.

3. Aplikasi Game 3D Tebak Rumah dan Busana Adat Nusantara Berbasis Android diimplementasikan dengan aplikasi Unity $3 D$ yang dibantu oleh library playmaker untuk dapat melakukan rotasi pada objek.

4. Berdasarkan hasil pengujian disimpulkan bahwa aplikasi Game 3D Tebak Rumah dan Busana Adat
Nusantara Berbasis Android dapat digunakan pada berbagai perangkat Android dengan spesifikasi yang telah ditentukan dan semua fitur yang ada dapat berjalan dengan baik.

5. Perbandingan antara gambar asli rumah dan busana adat dengan objek 3D-nya sudah cukup mirip.

6. Aplikasi Game 3D Tebak Rumah dan Busana Adat Nusantara Berbasis Android ini dapat dimanfaatkan sebagai sarana atau media yang menarik dalam memperkenalkan serta melestarikan kebudayaan Indonesia khususnya rumah dan busana adat tanpa perlu mengeluarkan biaya yang mahal untuk berkunjung ke taman budaya atau berkeliling Indonesia.

Berdasarkan hasil penelitian pengembangan dan kesimpulan, dapat disarankan bagi pembaca yang ingin mengembangkan sistem ini sebagai berikut.

1. Objek busana yang ada dalam aplikasi ini memiliki kapasitas yang besar dan berat, jadi untuk pengembangan selanjutnya agar diusahakan untuk membuat objek $3 D$ yang lebih ringan tetapi tetap detail.

2. Untuk pengembangan aplikasi selanjutnya, agar bisa ditambahkan fitur zoom dalam menu Pengenalan Objek.

3. Untuk pengembangan aplikasi selanjutnya, agar ditambahkan jumlah levelnya supaya pemain lebih tertantang dalam menyelesaikan permainan.

\section{DAFTAR PUSTAKA}

Dewanto, Rudy. 2011. "Rumah Adat Indonesia".

http://www.rudydewanto.com/2011/01 /rumah-adat-indonesia.html(diakses pada tanggal 26 Januari 2014).

Ahira, Anne. 2013. "Pakaian Adat Indonesia".

http://www.anneahira.com/pakaianadat-indonesia.htm(diakses pada tanggal 30 Januari 2014). 
Taman Nusa. 2013. "Lokasi". http://www.taman-nusa.com/lokasitaman-nusa.htm(diakses pada tanggal 3 Februari 2014).

Bambang et.al. 2010. IImu Pengetahuan Sosial untuk Sekolah Dasar/MI Kelas 4. Jakarta: Pusat Perbukuan Kementerian Pendidik.

Setyobudi, Toni. 2013. "Fahombo Game Lompat Batu ala Pulau Nias". http://www.aplikanologi.com/games/fa hombo-game-lompat-batu-ala-pulaunias/(diakses pada tanggal 22 Maret 2014).
Redaksi Cerdas Interaktif. 2012. Atlas Bergambar Seni \& Budaya Indonesia. Jakarta : Cerdas Interaktif.

Amrullah, Ahmad. 2012. "Pakaian Adat Tradisional Indonesia". http://www.azamku.com/pakaianadat-tradisional-indonesia/(diakses pada tanggal 7 Maret 2014).

Safaat, Nasrudin. 2012. Pemrograman Aplikasi Mobile Smartphone dan Tablet PC Berbasis Android. Bandung : Informatika. 